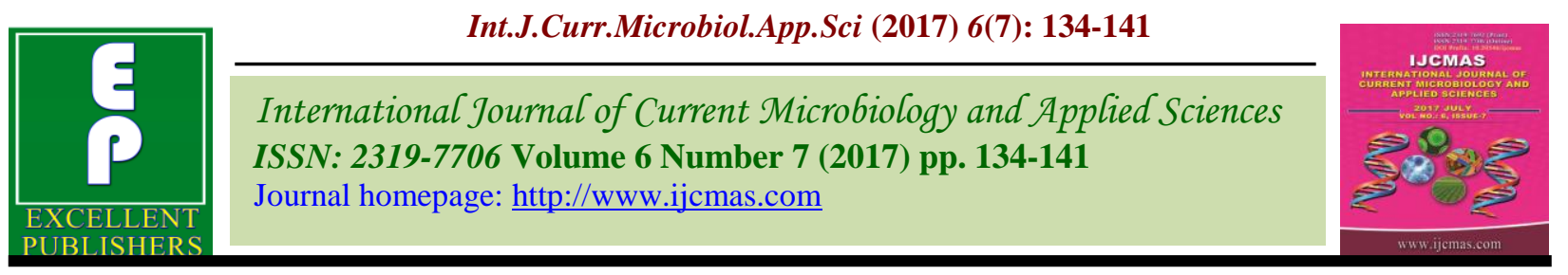

Review Article

https://doi.org/10.20546/ijcmas.2017.607.016

\title{
Role of Male Sterility in Vegetable Hybrid Seed Production
}

\author{
Mopidevi M. Nagaraju*", T. Thomson, G. Koteswara Rao and M. Siva \\ College of Horticulture, Dr. YSR Horticultural University, Venkataramannagudem-534101, \\ Tadepalligudem, West Godavari, Andhra Pradesh, India \\ *Corresponding author
}

\begin{tabular}{|c|c|}
\hline & A B S T R A C T \\
\hline Keywords & $\begin{array}{l}\text { Hybrid varieties play a vital role in increasing vegetable production due to } \\
\text { their high yield potential, early maturing, superior quality, disease and pest }\end{array}$ \\
\hline $\begin{array}{l}\text { Vegetables, } \\
\text { Hybrids, Male } \\
\text { Sterility, GMS, } \\
\text { CMS and CGMS. }\end{array}$ & $\begin{array}{l}\text { resistance attributes. Male sterility in vegetables is commercially utilized to } \\
\text { develop hybrids and substantial progress has made in understanding the } \\
\text { mechanism of male sterility. This review describes different types of male }\end{array}$ \\
\hline Article Info & commercially utilized in chilli and cucurbits crops, while CMS utilized in \\
\hline $\begin{array}{l}\text { Accepted: } \\
\text { 04 June } 2017 \\
\text { Available Online: } \\
\text { 10 July } 2017\end{array}$ & $\begin{array}{l}\text { cole crops and root crops. It is of special interest for plant breeders to } \\
\text { produce more efficient and economic hybrid seed trough male sterility. } \\
\text { Male sterility helps much to reduce the cost of hybrid seed production in } \\
\text { vegetables. }\end{array}$ \\
\hline
\end{tabular}

\section{Introduction}

Due to ever-increasing demand of vegetables in our country, the use of hybrids become popular to fulfil the recommended consumption level of $300 \mathrm{~g}$ vegetables per capita per day. In the past two decades, in most of vegetable crops such as tomato, cabbage, okra, capsicum, gourds and melons, the open pollinated varieties are being replaced with the hybrids ones. The introduction of hybrids in public and private sector has greatly boosted up the vegetable production in our country (De and Bhattacharjee, 2011). The prospect of increasing vegetable production by increasing land under vegetable cultivation is very limited in India. Hence it is imperative to increase the productivity of vegetables in order to meet the future demand, to accomplish the objective of food and nutritional security. In this context, hybrid vegetable technology is the better option to increase productivity. Vegetable hybrids under optimum crop production and protection management produce economically more yield than improved open-pollinated varieties. Further, uniform size, earliness, better adaptability to adverse environments, better transportability, better keeping quality and resistance to stress are certain additional advantages of growing hybrid vegetables. During the past decade vegetable hybrid technology has emerged as one of the most potential technologies in Indian agriculture production system and in coming decade also 
it has to go a long way in this country to meet future challenges. The commonly employed genetic mechanisms for overcoming emasculation and hand pollination and facilitating natural pollination is use of male sterility lines provide an asset particularly in crops which produce small sized flowers making hand emasculation tedious. It is of special interest for plant breeders to produce more efficient and economic hybrid seed. These techniques help much to reduce the cost of hybrid seed production.

\section{Male sterility}

Male sterility refers to a condition in which pollen is either absent or non-functional in flowering plants, while female gametes function normally.

\section{History of male sterility}

In flowering plants, the first report of male sterility by Koelreuter in 1763.

First report of male sterility in onion is reported by Jones and Clarke in 1943.

Male sterility in carrot was first reported by Welch and Grimball in 1947.

Male sterility in pepper was first documented by Martin and Grawford in 1951.

Genic male sterility has been reported in cabbage and cauliflower by Nieuwhof in 1961.

\section{Classification of male sterility}

There are three basic types of male sterility. (1) Genetic male sterility, (2) Cytoplasmic male sterility and (3) Cytoplasmicgenetic/genic male sterility. There are two other types, viz., chemical induced male sterility and transgenic male sterility.

\section{Genetic Male Sterility (GMS)}

The pollen sterility is caused by nuclear genes is termed as genic or genetic male sterility. This type of sterility has been reported in several crop plants like tomato, pepper, brinjal and cucurbits, cole crops.

\section{Hybrid seed production procedure for GMS based hybrids}

The hybrid seed is produced in the open in an isolated field, called 'hybrid seed production block'. The female and male lines are planted alternatively in the ratio of 2:1 (Fig. 1). The female line produces both the male fertile and male sterile plants in the ratio of $1: 1$. The female line is first prepared for cross pollination for hybrid seed production by removing the male fertile plants. In general, male sterile plants are morphologically not distinguishable from the sister fertile plants, except in few cases, were male sterile flower size is smaller than that of fertile flowers e.g. chilli.

\section{Cytoplasmic male sterility (CMS)}

This type of male sterility is determined by the cytoplasm. Since the cytoplasm of a zygote comes primarily from egg cell, the progeny of such male sterile plants would always be male sterile. CMS can be transferred easily to a given strain by using that strain as a pollinator (recurrent parent) in the successive generations of backcross programme. After 6-7 backcrosses, the nuclear genotype of the male sterile line would be almost identical to the recurrent pollinator strain (Fig. 2).

\section{Utilization of CMS}

Cytoplasmic male sterility can be maintained by crossing a male sterile line ( $A$ line) with the pollinator strain (maintainer line) used as 
a recurrent parent in the back cross programme since the nuclear genotype of the pollinator is identical with that of the new male sterile line. Such a male fertile line is called the maintainer line or $B$ line as it is used to maintain the male sterile line. CMS can be utilized for hybrid seed production in those vegetables where vegetative part is of economic value e.g. onion, carrot, radish, cole crops, etc.

\section{Cytoplasmic genic male sterility (CGMS)}

This is a case of cytoplasmic male sterility where a nuclear gene for restoring fertility in the male sterile line is known. The fertility restorer gene, $R R$ is dominant and is found in certain strain of the species or may be transferred from a related species. The sterility factor is determined by interaction of nuclear genes and cytoplasm but none of them singly can control sterility. This type of sterility is reported in carrot, onion, chilli, capsicum and Brassica napus.

New male sterile line may be developed following the same procedure as cytoplasmic system, but the nuclear genotype of the pollinator strain in such a transfer must be $N N-r r$ otherwise the fertility would be restored.

\section{Utilization of CGMS}

CGMS can be maintained by crossing a cytoplasmic male sterile line $(S S-r r)$ or $A$ line with the pollinator strain $(N N-r r)$ used as recurrent parent in the backcross programme since the nuclear genotype of the pollinator is identical with that of new male sterile line (Fig. 3). Such a male fertile line is known as maintainer line or $B$ line as it is used to maintain the male sterile line.

For hybrid seed production, 2 to 3 rows of line $A(S S$-rr) are alternated with 1 row of line
$C$, which is generally expected to $N N-R R$. The seed is harvested from $A$ line for use as commercial hybrid seed. The line $C$ may have genotypes $N N-r r, N N-R r, S S-R r, S S-R R$, but the hybrid developed by using any of the first three genotypes will be sterile and can be used where seed is not a commercial product but where seed is important, pollen parent should have genetic constitution $N N-R R$. The main advantage of CGMS system over GMS is that we can get $100 \%$ male sterile plants for direct use as female.

\section{Role of male sterility in vegetables}

\section{Chilli (Capsicum annuum L.)}

In chilli, the Punjab Agricultural University (PAU) has developed MS-12 line, which carries genetic male sterility (GMS) controlled by recessive gene (msms). The male sterile line (MS-12) was developed by transferring sterility gene ( $m s-509$, renamed as $m s-10$ ) from capsicum (imported from France) into the cultivar 'Punjab Lal' through back crossing (Singh and Kaur, 1986). By using this male sterile line (MS-12), PAU has released two chilli hybrids viz. CH-1 (Hundal and Khurana, 1993) and CH-3 (Hundal and Khurana, 2001), showing heterosis of 80$100 \%$ and out yielded all the recommended chilli varieties. The male sterile line (female), MS-12, is common in both these hybrids. The male parents are Ludhiana Local Selection (LLS) and Selection-2530 (S- 2530) in CH-1 and $\mathrm{CH}-3$, respectively. On the basis of their high yield potential, multiple disease resistance and quality attributes, their acceptance has been very fast and, consequently, the acreage under chilli increased about 3 folds in the last 6-7 years in Punjab State and is likely to increase further in the near future. There is great acceptance of $\mathrm{CH}-1$ in other states especially Haryana and Rajasthan. 
The CGMS in chilli was first reported by Peterson (1958) in an introduction of $C$. annuum from India (PI-164835), however, it has not been exploited commercially, because of instability under fluctuating conditions, particularly temperatures and a low rate of natural cross pollination in cultivated hot pepper (Kumar et al., 2007).

The World Vegetable Centre, Taiwan has identified two CGMS lines (A lines) in chilli i.e. CCA-4759 and CCA-4757, which were found to be reliably sterile under conditions of night temperatures less than $15^{\circ} \mathrm{C}$ (Liu and Gniffke, 2004). A hybrid 'Jingla No 2' of chilli was developed by crossing CMS line 181 a with the restorer line 98199 (Geng et al., 2005). In the recent past in India, chilli CGMS lines (CCA-4261) have been introduced at IIVR from The World Vegetable Centre, which are utilized directly or indirectly to produce CGMS based hybrid i.e. Kashi Surkh. A total of 9 sets of A and B lines are being maintained at IIVR and 5 promising CGMS based hybrid combinations viz., A 2 x Pusa Jwala, A3 x Pusa Jwala, A2 x Pant C1, A3 x Japani Longi and A7 x Pant C1 have been identified. At IIHR, Bangalore three chilli hybrids viz., Arka Meghana, Arka Sweta, Arka Harita and Arka Khyati are developed using the CGMS lines developed at the institute. PAU, Ludhiana is also working on utilization of CGMS in chilli.

\section{Cucurbitaceous vegetables}

The cucurbit vegetables have larger size of male and female flowers and allow following other systems of pollination control strategies. Most of the genetic male sterile mutants in cucurbits are monogenic recessive.

There are several male sterile types are identified, but commercial exploitation is still lacking. Among the cucurbits male sterility is commercially exploited and utilized in musk melon.
Five male sterile genes ( $m s-1, m s-2, m s-3, m s-$ 4 , and $m s-5$ ) have been identified in melon (Cucumis melo L.) and all of them are recessive and non-allelic. In a greenhouse study $\left(24^{\circ} \mathrm{C}\right.$ night, $32^{\circ} \mathrm{C}$ day), it has been observed that male-sterile plants in $m s-1$ and $m s-2$ progenies are difficult to identify as the aberrant flowers are observed on genetically fertile siblings and thus the expression of these genes is unstable (McCreight, 1984), which could lead to genetic impurity in $F_{1}$ hybrid seed. In India, male-sterile gene $m s-1$ was introduced in 1978 and used to release two commercial cultivars 'Punjab Hybrid' (Nandpuri et al., 1982) and 'Punjab Anmol' (Lal et al., 2007).

The first male sterility in Watermelon, Citrullus lanatus (Thunb.) was reported by Watts (1962) who found a male sterile mutant in the X2 generation of 'Sugar Baby' irradiated with gamma rays. The mutant was described as a glabrous male sterile ( $\mathrm{gms}$ ) due to the associated lack of hairs on the plant foliage (Watts, 1962). Glabrousness and male sterility were inherited together as a single recessive nuclear gene, suggesting very close linkage or a pleiotropic effect of the locus involved (Watts, 1967). The gms gene not only disrupts the male reproductive function, but also reduces female reproduction (Watts, 1967). Therefore, there has been little commercial application of the gms gene (Zang et al., 1994).

\section{Cole crops (Brassica oleracea L.)}

In cole crops, $F_{1}$ hybrids are advantages especially in uniform maturity, high early and total yield, better curd/ head quality with respect to compactness, color, resistance to insect- pests, diseases and heat tolerance.

In Brassica oleracea L. first CMS system was developed by Pearson (1972) through interspecific hybridization between $B$. nigra and 
B. oleracea var italica. Back crosses were also made between the amphidiploids and cabbage cultivar Green Globe and from these materials Pearson established two CMS systems, viz., petaloid and vestigial anther male sterility. Flowers of petaloid male sterile plants were less attractive to the pollinating insects, since pistils were enlarged, malformed and were lacking in nectarines (Pearson, 1972). In vestigial anther types, although flowers were smaller, normal and with functional nectarines, homozygous plants could not be recovered even after six generations of backcrossing in broccoli (Dickson, 1975).

\section{Ogura cytoplasm}

CMS has been reported in an identified cultivar of Japanese radish by Ogura (1968) and first alloplasm was introduced by introgression of this sterility cytoplasm to Brassica oleraceae genome through repeated backcrosses with broccoli (Bannerot et al., 1974). Later Dickson (1975) and HoserKrauze (1987) transferred it from broccoli to cauliflower. In India this sterile cytoplasm from broccoli was transferred and established in three different maturity genetic backgrounds of Indian cauliflowers viz., early, mid and mid late through hybridization.

The curd yield is increased $40-75 \%$ compared to SI system from different maturity groups (Pritam Kalia, 2008). Recently Ogura based CMS lines developed in snowball cauliflower viz., Ogu1A, Ogu2A and Ogu3A for hybrid development in cauliflower. In India, IARI regional station Katrain develops two cabbage hybrids $\mathrm{H}-64$ and $\mathrm{KCH}-4$ using cytoplasmic male sterility.

Fig.1 General scheme of hybrid seed production utilizing GMS

\begin{tabular}{|c|c|c|c|c|}
\hline Male Sterile Maintainer Block & \multicolumn{4}{|c|}{ Hybrid Seed Production Block } \\
\hline msms (o) $\quad X$ & $\bullet$ & o & & \\
\hline Male sterile & & + & & \\
\hline & & o & $\bullet$ & \\
\hline$[50 \%$ msms (o) : $50 \%$ Msms (+) ] & + & + & - & \\
\hline Male sterile : Male fertile & & o & $\bullet$ & \\
\hline Seeds collected from male sterile & $\bullet$ & $\begin{array}{l}0 \\
+\end{array}$ & $\bullet$ & \\
\hline plants only (after identification) & - & + & - & \\
\hline
\end{tabular}

Fig.2 General scheme of hybrid seed production utilizing CMS

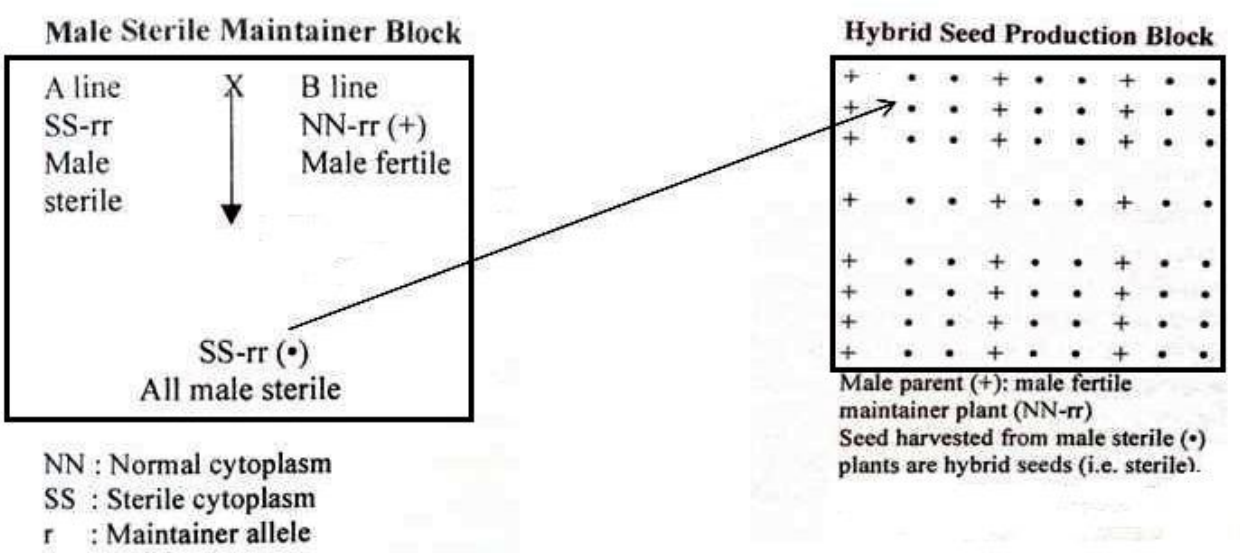




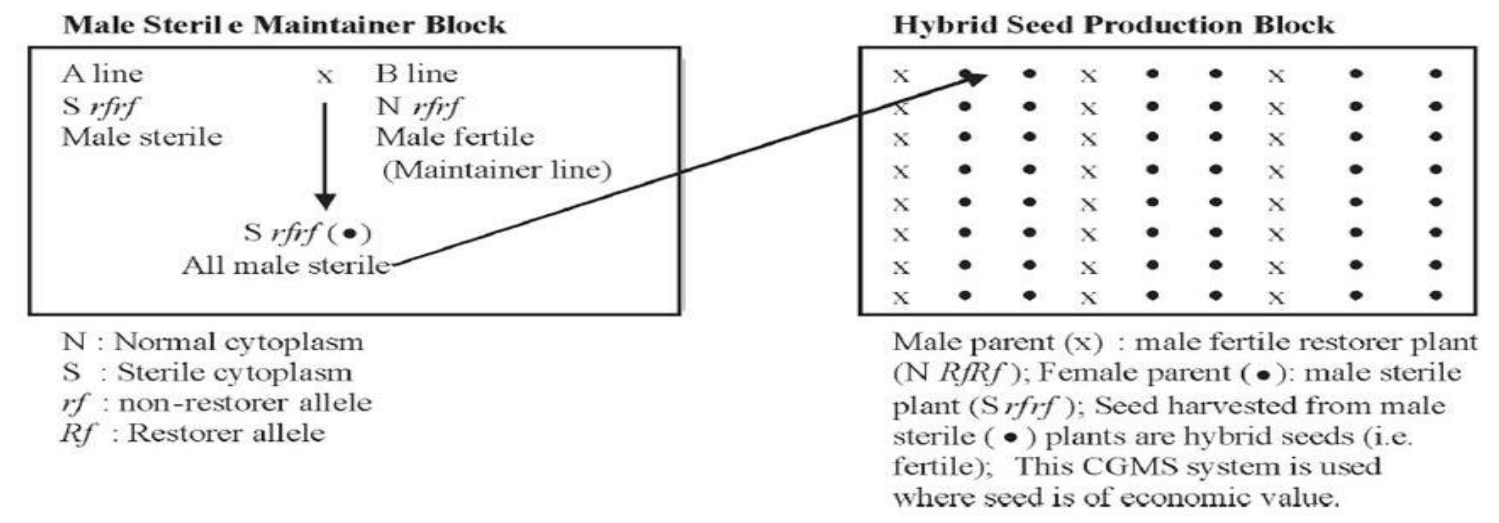

Fig.3 General scheme of hybrid seed production utilizing CGMS

\section{Root crops}

\section{Carrot (Daucus carota L.)}

Cytoplasmic male sterility in carrot can occur in two morphologically distinct phenotypes.

\section{Brown anther type}

The brown anther $(b a)$ male sterility was first discovered in the cultivar Tendersweet and reported by Welch and Grimball in 1947. The results of Hanshe and Gabelman (1963), and Banga et al., (1964) suggested that expression of the brown anther sterility was due to a homozygous recessive locus $M s 5$ or a dominant allele for $M s 4$, but dominant allele of either of the two complimentary loci would restore the fertility.

\section{Petaloid male sterility}

Petaloid sterility is commercially used for hybrid seed production in the world. It is homeotic mutation.

This is manifested as the replacement of stamens with petals (white petaloidy) or both stamens and petals with green bract like structures (green petaloidy) (Kitagawa et al., 1994). It is stable across a wide range of environments through flowering and seed production.
CMS system has been established for the first time in asiatic carrot germplasm in India at IARI. The first public sector tropical carrot hybrid Pusa Vasudha has been developed by IARI, New Delhi. This male sterility utilized and developed a first in temperate carrot hybrid Pusa Nayanjyothi, at IARI regional station, Katrain. CMS was introduced in to carrot breeding materials, provides a very efficient tool for mass scale pollination control.

\section{Radish (Raphanus sativus L.)}

As in all other cruciferae members, cytoplasmic male sterility is reported in radish also. Ogura cytoplasm was first identified in Japanese radish and is controlled by single recessive gene and this is one which is extensively studied and is used for the production of hybrid seeds in radish. Male sterility expressions in the most of the populations have been reported to be stable, except on some population reversible temperature effect has been reported by Nieuwhof (1990).

\section{Bulb crops - Onion (Allium cepa L.)}

First CMS plant was reported within the progenies of an onion cultivar Italian Red (Jones and Emsweller, 1936) and male sterility was under the control of single 
recessive nuclear restorer locus (Jones and Clarke, 1943).

The first CMS source in onion was CMS-S type. This CMS source is more likely an alien cytoplasm and differs from $\mathrm{N}$ cytoplasm for many polymorphisms in the chloroplast and mitochondrial genome. The CMS-S system has been widely used because of its stability in various environments. The CMS line ( $S$ $\mathrm{ms} / \mathrm{ms}$ ) and its near isogenic maintainer line ( $N \mathrm{~ms} / \mathrm{ms}$ ) are essential to breed the $\mathrm{F}_{1}$ hybrid using the CMS system.

Worldwide more than $50 \%$ onion varieties currently cultivated are $F_{1}$ hybrids derived from S-cytoplasm. In India, the work gained momentum in the eighties at IIHR (Bangalore), IARI (New Delhi) and MPKV (Rahuri).

At IARI, male sterility was found in a commercial variety Pusa Red. Only two hybrids, Arka Kirtiman and Arka Lalima have been released by IIHR after development of CMS lines along with the maintainer.

The research on male sterility in vegetables is a never ending process due to rapid advancement of molecular techniques and their implementation. Substantial progress has been made in understanding the mechanism of male sterility in selected vegetable crops.

At global level, CMS and CGMS are the most widely utilized in most of the vegetables. Male sterility provide an asset particularly in crops like onion and carrot which produce many but small sized flowers making hand emasculation tedious. Through the utilization of male sterility we can reduce the hybrid seed cost nearly of 40 to $70 \%$. Genetically engineered male sterility provides tremendous opportunities to the breeders for enforcing pollination control in hybrid seed production systems.

\section{References}

Banga, O., Petiet, J. and Van Bennekom, J. L. 1964. Genetical analysis of male sterility in carrots, Daucus carota L. Euphytica 13: 75-93.

Bannerot, H., Boulidard, L., Cauderon, Y. and Temp, J. 1974. Transfer of cytoplasmic male sterility from Raphanus sativus to Brassica oleraceae. In: Proc. Eucarpia Meet. Cruciferae, Scott. Hort. Res. Inst., Dundee. Pp.52-54.

De LC and Bhattacharjee SK. 2011. Handbook of Vegetable Crops. Pointer Publisher, Jaipur. Pp.76-81.

Dickson, M. H. 1975. G1117A, G1102A and G1106A cytosterile broccoli inbreds. HortScience 10: 535.

Geng, S. S., Chen, B. and Zhang, X.F. 2005. A new hot pepper F1 hybrid "Jingla No. 2". China Veg. 10/11: 41-42.

Hansche, P. E. and Gabelman, W. H. 1963. Digenic control of male sterility in carrots, Daucus carota L. Crop Sci. 3: 383-386.

Hoser- Krauze, J. and Antosik, J. 1987. Horticultural value and seed setting of cytoplasmic male sterile cauliflower line with Raphanus sativus CMS (Bannerot). Eucarpia Cruciferae Newsl. 12: 34.

Hundal, J. S. and Khurana, D. S. 1993. 'CH1'-A new hybrid of chilli. Prog. Fmg. 29: 11-13.

Hundal, J. S. and Khurana, D. S. 2001. A new hybrid of chilli ' $\mathrm{CH}-3$ '- Suitable for processing. J. Res. Punjab agric. Univ. 39 (2): 326.

IIVR (Indian Institute of Vegetable Research) 2013. Vision 2050. Pp 1.

IARI (Indian Agriculture Research Institute) 2013. Annual report 2012-2013. Pp 19.

Johns, H. A. and Clarke, A. E. 1943. The story of hybrid onion. Proc. Am. Soc. Hort. Sci. 43: 189-194.

Jones, H. A. and Emsweller, S. L. 1936. A 
male sterile onion. Proc. Am. Soc. Hort. Sci. 63: 443.

Kalloo, G. 1988. Vegetable Breeding. Vol. I. CRC Press, Inc., Flordida. 23 p.

Kitagawa, J., Gerrath, J., Posluszny, U. and Wolyn, D. J. 1994. Developmental and morphological analysis of homeotic cytoplasmic male sterile and fertile carrot flowers. Sex. Plant Reprod. 7: 4150.

Kumar, S., Singh, V., Singh, M., Rai, S.K., Kumar, S., Rai, M. and Kalloo, G. 2007. Genetics and distribution of fertility restoration associated RAPD markers in pepper (Capsicum anпиит L.). Hort. Sci. 111: 197-202.

Lal, T., Vashisht, V. and Dhillon, N. P. S. 2007. Punjab Anmol - A new hybrid of muskmelon (Cucumis melo L.). J. Res. Punjab agric. Univ. 44: 83.

Nandpuri, K. S., Singh, S. and Lal, T. 1982. 'Punjab Hybrid' a variety of muskmelon. Prog. Fmg. 18: 3-4.

Nieuwhof, M. 1961. Male sterility in brusselsprout, cauliflower and cabbage. Euphytica 10: 351-356.

Nieuwhof, M. 1990. Cytoplasmic-genetic male sterility in radish (Raphanus sativus L.), identification of maintainer, inheritance of male sterility and effect of environmental factors. Euphytica 47: 171-177.

Ogura, H. 1968. Studies of the male sterility in japanese radish with special referance to the utilisation of this sterility towards the practical raising of hybrid seeds. Meum. Fac. Agriculture, Kagoshima
University. 6: 39-78.

Pearson, O. H. 1972. Cytoplasmically inherited male sterility characters and flavor component from the species Brassica napus. J. Am. Soc. Hort. Sci. 392-402.

Peterson, P. A. 1958. Cytoplasmically inherited male sterility in Capsicum. Am. Naturalist 92: 111-19.

Singh, J. and Kaur, S. 1986. Present status of hot pepper breeding for multiple disease resistance in Punjab. Proceeding of VI EUCARPIA Meeting on Genetic and Breeding on Capsicum and Eggplant, Zaragoza (Spain). Pp.111-114.

Stanghellini, M. S., Ambrose, J. T. and Schultheis, J. R. 1998. Seed production in watermelon: A comparison between two commercially available pollinators. Hort-Science 33:28-30.

Watts, V. M. 1962. A marked male-sterile mutant in watermelon. Proc. Am. Soc. Hort. Sci. 81: 498-505.

Watts, V. M. 1967. Development of disease resistance and seed production in watermelon stocks carrying $m s g$ gene. J. Amer. Soc. Hort. Sci. 91: 579-580.

Walters, S. A. 2005. Honey bee pollination requirements for triploid watermelon. Hort Science 40:1268-1270.

Welch, J. E. and Grimball, E. L. 1947. Male sterility in the carrot. Sci. 106: 594.

Zhang, X. P., Skorupska, H. T. and Rhodes, B.B. 1994. Cytological expression in the male-sterile $m s$ mutant in watermelon. J. Hered. 85: 279-285.

\section{How to cite this article:}

Mopidevi M. Nagaraju, T. Thomson, G. Koteswara Rao and Siva, M. 2017. Role of Male Sterility in Vegetable Hybrid Seed Production. Int.J.Curr.Microbiol.App.Sci. 6(7): 134-141. doi: https://doi.org/10.20546/ijcmas.2017.607.016 